\title{
The psychology behind commitment and loyalty : an empirical study in a bank setting
}

Citation for published version (APA):

Bloemer, J. M. M., Odekerken-Schröder, G. J., \& Martens, H. (2002). The psychology behind commitment and loyalty : an empirical study in a bank setting. METEOR, Maastricht University School of Business and Economics. METEOR Research Memorandum No. 058 https://doi.org/10.26481/umamet.2002058

Document status and date:

Published: 01/01/2002

DOI:

10.26481/umamet.2002058

Document Version:

Publisher's PDF, also known as Version of record

\section{Please check the document version of this publication:}

- A submitted manuscript is the version of the article upon submission and before peer-review. There can be important differences between the submitted version and the official published version of record.

People interested in the research are advised to contact the author for the final version of the publication, or visit the DOI to the publisher's website.

- The final author version and the galley proof are versions of the publication after peer review.

- The final published version features the final layout of the paper including the volume, issue and page numbers.

Link to publication

\footnotetext{
General rights rights.

- You may freely distribute the URL identifying the publication in the public portal. please follow below link for the End User Agreement:

www.umlib.nl/taverne-license

Take down policy

If you believe that this document breaches copyright please contact us at:

repository@maastrichtuniversity.nl

providing details and we will investigate your claim.
}

Copyright and moral rights for the publications made accessible in the public portal are retained by the authors and/or other copyright owners and it is a condition of accessing publications that users recognise and abide by the legal requirements associated with these

- Users may download and print one copy of any publication from the public portal for the purpose of private study or research.

- You may not further distribute the material or use it for any profit-making activity or commercial gain

If the publication is distributed under the terms of Article $25 \mathrm{fa}$ of the Dutch Copyright Act, indicated by the "Taverne" license above, 
THE PSYCHOLOGY BEHIND COMMITMENT AND LOYALTY

AN EMPIRICAL STUDY IN A BANK SETTING

\author{
Josée Bloemer*, Gaby Odekerken- Schröder**, Hilda Martens***
}

* PhD, Full Professor of Marketing and Market Research, University of Nijmegen, P.O. Box 9108, $6500 \mathrm{HK}$ Nijmegen, the Netherlands, tel: +31 24 3613018, fax: +31 24 3611933, e-mail: j.bloemer@nsm.kun.nl

** PhD, Associate Professor of Marketing, Maastricht University, P.O. Box 616, 6200 MD Maastricht, the Netherlands, tel: +31 43 3883618, fax: +31 43 3884918, e-mail: g.schroder@mw.unimaas.nl

*** PhD, Assistant Professor in Human Resource Management, Limburg University Centre, University Campus, Building D, 3590 Diepenbeek, Belgium, tel: +32 1126 8662, fax: + 321126 8700, e-mail hilda.martens@luc.ac.be 


\section{THE PSYCHOLOGY BEHIND COMMITMENT AND LOYALTY}

AN EMPIRICAL STUDY IN A BANK SETTING

\section{ABSTRACT}

Despite the extant literature on customer loyalty, it is recognized that the psychological processes behind commitment and customer loyalty are still ill understood. Therefore, the primary objective of this study is to assess the impact of three psychological antecedents (position involvement, volitional choice and informational complexity) on affective, calculative and normative commitment to a bank. In turn, we assess the impact of an individual difference variable (consumer relationship proneness) on these three psychological antecedents. And finally, this research project addresses the consequences of affective, calculative and normative commitment on loyalty in terms of word of mouth, purchase intention, price insensitivity and complaining. An empirical research among 439 bank customers was conducted to test our conceptual model. Structural Equation Modeling (SEM) results reveal the pivotal role of affective commitment as an antecedent of customer loyalty. In turn, affective commitment can best be explained by position involvement. Moreover, relationship proneness seems to be most strongly related to position involvement. Managerial implications, limitations and directions for future research are provided. 


\section{INTRODUCTION}

Despite the extant literature on customer loyalty, it is recognized that the psychological processes behind customer loyalty and commitment are still ill understood (Pritchard et al. 1999). The objective of our study is threefold. First, we assess the three psychological antecedents of commitment to a bank. Second, we study an individual difference variable underlying these antecedents of commitment. Finally, we investigate the influence of affective, calculative and normative commitment on customer loyalty in a bank setting.

In the literature on organizational psychology, Allen and Meyer (1990) distinguish between affective, continuance (calculative) and normative commitment. The differences between these three types of commitment reflect the psychological state that binds the individual to the organization. Affective commitment refers to the emotional attachment to an organization, while continuance commitment refers to the costs that individuals associate with leaving the organization and the normative component refers to individuals' feelings of obligation to remain with the organization. They argue, that a more comprehensive understanding of the link between commitment and loyalty will be achieved when all three types of commitment are considered simultaneously.

Pritchard et al. (1999) argue that an analysis of commitment 'should move beyond a general expression of attachment and incorporate an understanding of the psychology inherent in binding a person to that disposition' (p. 334). They distinguish information processes, identification processes and volition processes as antecedents of commitment. As we want to grasp the psychology behind commitment, we will assess these three antecedent processes simultaneously in a single study.

Finally, our aim is to move beyond an assessment of the antecedent processes and investigate their origin in terms of a recently introduced individual difference variable 
"consumer relationship proneness". Consumer relationship proneness refers to the idea that some customers are intrinsically inclined to engage in relationships (De Wulf et al. 2001). It has been shown that consumer relationship proneness has a positive impact on commitment and loyalty (De Wulf et al. 2001). We consider relationship proneness as an individual difference variable that activates the psychological processes underlying commitment.

The studies mentioned before focus on a single aspect: either types of commitment, or the psychological processes behind commitment or consumer relationship proneness. Despite their tremendous contribution to the field, we aim at providing a complete picture by investigating these aspects simultaneously. Therefore in this study we investigate the relationships between consumer relationship proneness; the three antecedents of commitment; the three types of commitment and customer loyalty in terms of word-of-mouth, purchase intentions, price insensitivity and complaining in a bank setting.

We continue with a description of the theoretical background of our conceptual model. Next, we formulate hypotheses about the interrelationships between the concepts. Then, we describe the research design and the results of the empirical research conducted. Finally, we come up with conclusions, managerial implications, limitations and recommendations for future research.

\section{THEORETICAL BACKGROUND}

Figure 1 shows the conceptual model underlying this study. In this section, we will first elaborate upon the three types of commitment, followed by their antecedent constructs and consumer relationship proneness. Finally, we address the four types of customer loyalty. 
Insert Figure 1 about here

\section{Commitment}

Commitment is generally referred to as an enduring desire to maintain a relationship (Morgan and Hunt 1994). The concept of commitment is similar to the concept of a long-term orientation that comprises the desire and utility of a buyer to have a long-term relationship with a seller (Gruen 1995). In line with Day (1969), Dick and Basu (1994) stated that the stronger commitment, the more likely the buyer is to overcome potential obstacles in the buyer-seller relationship, resulting in customer loyalty. Similarly, Beatty, Homer, and Kahle (1988) state that commitment and loyalty are related, yet by definition distinct constructs, with commitment leading to loyalty.

In this research we distinguish three different types of commitment: affective commitment, calculative commitment and normative commitment. Affective commitment can be defined as “a party's desire to continue a relationship because of the enjoyment of the relationship for its own sake, apart from the instrumental worth and because they experience a sense of loyalty and belongingness" (Allen and Meyer, 1990; Geyskens et al. 1996). Calculative or continuance commitment can be defined as "the degree to which channel members experience the need to maintain a relationship, given the significant perceived termination of switching costs associated with leaving”. It is the cold calculation of costs and benefits, including investments and available alternatives to replace or make-up for foregone investments (Allen and Meyer, 1990; Geyskens et al. 1996). And normative commitment is reflected in "the (moral) obligation to stay in a relationship" (Allen and Meyer, 1990). In line with Allen and Meyer (1990), Geyskens (1998, p. 50) states that 'the use of global commitment measures - which measure intention to continue a relationship without 
consideration of the underlying motivation - could confound or mask different, and possibly even opposite effects'.

Psychological antecedents of commitment

Since commitment is a desirable outcome it is valuable to gain insights into its antecedent processes. Position involvement, volitional choice and informational complexity represent the three psychological formative processes distinguished by Pritchard et al. (1999): identification processes, volitional processes and informational processes.

In our context, the identification process refers to the question whether customers identify themselves with the values and images embodied by a particular bank. It is expected that the more strongly customers identify themselves with the bank, the stronger their commitment towards the bank. The volitional process refers to customers' perceptions that their preferences are free and not dictated by any constraints. When customers sense that their choice for the bank is unhindered, the resulting commitment is likely to be stronger and more deeply held (Pritchard et al. 1999). Finally, the informational process distinguished by Pritchard et al. (1999) deals with cognitive structures and how customers manage information about their preferred bank. It is assumed, that the need to maintain a consistent informational structure, about for instance reasons for revisiting the bank, has a positive impact on commitment.

\section{Position involvement}

Position involvement is considered to be an important construct representing the identification process. Position involvement is defined as "a situation in which important values or selfimages are identified with a particular bank choice” (cfr. Freedman, 1964). Customers' position involvement is determined by the extent to which the customer's public association 
with the service in question is in line with certain values and self-images of that customer. Some researchers even indicate that the highest form of commitment is driven by the need for social representation and self-identity (Buchanan 1985).

Volitional choice

According to Pritchard et al. (1999) volitional choice, being a construct representing the volitional process, can be defined as "a process that involves both a freedom from constraints and a freedom to choose”. In our setting, freedom from refers to the notion that a bank choice is elicited freely and not constrained by external considerations that might limit a customer's sense of personal responsibility in that decision. The freedom to component of volitional choice refers to the potential for a choice to reflect meaningful action or effort (Bagozzi, 1993). Research suggests that when people sense they are acting freely in choosing an object, they attribute meaning toward that object (Bem, 1967). For instance, when customers choose 'First American Bank' or another bank from a wide range of banks, they usually infer greater meaning in that selection (e.g. "It's my favorite or the best alternative").

Informational complexity

Informational complexity is deemed to be an important construct representing the informational process. Informational complexity can be defined as "the extent to which information processing is required to form cognitive structures". Pritchard et al. (1999) claim that when complex informational schema underlie customers' commitment, changing their mind becomes more difficult as accommodating disparate cognitions require even greater change (Millar and Tessar, 1986). Moreover, deviation from an attitude that is supported by a complex cognitive structure involves higher psychological costs than deviation from an attitude that is supported by a simple cognitive structure (Salancik, 1977). 


\section{Consumer Relationship Proneness}

Knowing which psychological processes underlie commitment is step one. But for banks it is interesting to know which customers are most inclined to reveal these desirable antecedent processes. Therefore, we investigate the individual difference variable of consumer relationship proneness. In this study, in line with De Wulf et al. (2001), we define consumer relationship proneness as "a consumer's relatively stable and conscious tendency to engage in relationships with retailers of a particular product category." In the current context, consumer relationship proneness refers to the stable tendency of a customer to engage in relationships with banks and can therefore be considered as an individual difference variable. In addition, we emphasize a conscious tendency to engage in relationships as opposed to a tendency to engage in relationships based on inertia or convenience (e.g., Dick and Basu 1994). Moreover, the concept of proneness is focused on the tendency to engage in relationships as opposed to the tendency to maintain or enhance relationships. The latter would not be generic as it would be contingent upon a particular bank, leading to a close resemblance to the construct of commitment. Finally, since several authors stress that a buyer's proneness to engage in relationships might vary across groups of sellers (Barnes 1997; Bendapudi and Berry 1997; Christy, Oliver, and Penn 1996) (e.g., banks versus supermarkets), we postulate that consumer relationship proneness differs across service retailers of different product categories (e.g. hotels, banks, supermarkets etc.). Bagozzi (1975, p. 33) already stated that "retailers, for example, know that they will not obtain repeat purchases if the consumer is taken advantage of and deceived". While many relationship marketing studies dealt with relationships based on dependence and locking in buyers (constraint-based relationships), consumer relationship proneness focuses on positive motivations of customers driven by a stable and conscious tendency to engage in relationships with sellers (dedication-based relationships) (Barnes 1995/1997; Davis 1995; Ganesan 1994; 
Oliver and Swan 1989; Palmer 1995; Smith and Barclay 1997). Christy, Oliver, and Penn (1996) used the term "psychologically predisposed" in order to express the idea that some buyers are intrinsically inclined to become loyal to a retailer.

\section{Customer Loyalty}

In line with Jacoby and Chestnut (1978) we define customer loyalty as the "biased (i.e. non random) behavioral response, expressed over time, by some decision making unit, with respect to one bank out of a set of banks, which is a function of psychological (decision making and evaluative) processes resulting from commitment".

The conceptualization and measurement of loyalty has often remained limited, ignoring the full range of conceivable loyalty (re)-actions that may follow the evaluation of a service (Zeithaml et al. 1996). Cronin and Taylor (1992) for instance focused solely on repurchase intentions, while Bolding et al. (1993) measure repurchase intentions and willingness to recommend. As Zeithaml et al. (1996) argue, dimensions of loyalty, such as, willingness to pay more, and loyalty under increased pricing have often been left out in previous research. Similarly, customer evaluations following a negative service experience have received only limited attention in scales designed to measure customer loyalty intentions and behavior (Singh 1991). With regard to behavioral intentions in a service setting Zeithaml et al. (1996) proposed a comprehensive, multi-dimensional framework of customer behavior intentions in services. This framework was conceptually comprised of the following four main dimensions: (1) word-of-mouth communications, (2) purchase intentions, (3) price sensitivity, and (4) complaint behavior. In this paper, we therefore also distinguish these four biased behavioral responses. 


\section{THE INTERRELATIONSHIPS BETWEEN THE CONCEPTS}

By definition, relationship proneness refers to a conscious tendency to engage in relationships with banks (De Wulf et al. 2001). This tendency to engage in relationships is supposed to have a direct positive influence on the antecedents of commitment in terms of position involvement, volitional choice and informational complexity. Relationship proneness will have a positive impact on position involvement as relationship prone customers will be more eager to identify themselves with a particular bank choice that reflects their important values or self-images, than customers who are not relationship prone (Freedman 1964). Moreover, we expect relationship proneness to have a positive influence on volitional choice since especially relationship prone customers will value dedication-based relationships as opposed to constraint-based relationships. These relationship prone customers will appreciate a voluntary choice, in term of a freedom from constraints and a freedom to choose, for a particular bank more than customers who are not relationship prone (Bem 1967). Finally, relationship proneness will have a positive impact on informational complexity because it can be expected that customers who are relationship prone will have more complex cognitive structures to make a conscious choice for a particular bank than customers who are not relationship prone (Festinger 1957). By definition relationship proneness is a conscious tendency to engage in relationships, which implies that relationship prone customers actively process information concerning particular bank relationships. Therefore, we formulate the following hypothesis:

H1 There is a positive relationship between relationship proneness and (a) position involvement, (b) volitional choice and (c) informational complexity 
Crosby and Taylor (1983) suggested that the congruence between a customer's personal values and self-images (position involvement) and the values and norms embodied by a product or service, strengthens commitment. This implies that a customer who considers a particular bank to represent important personal values will show a stronger commitment towards this bank. Cialdini et al. (1978) argued that once volitional processes were engaged, customers develop a sense of commitment in which they were prepared to continue with an initial decision, even though certain sales incentives were withdrawn. In line with Festinger (1957) we argue that much of a customer's commitment is driven by the psychological cost (informational complexity) involved in the cognitive reordering and rethinking of what was known about the bank. Pritchard et al. (1999) found empirical support for the positive relationships between position involvement, volitional choice, informational complexity and commitment as a one-dimensional construct. To the best of our knowledge, no other study investigated the impact of the three psychological antecedents of commitment on the three distinct types of commitment as such. Therefore, in line with these preliminary findings, we extend the positive relationship between the antecedents and commitment as a onedimensional construct to the three distinct types of commitment and hypothesize:

$\mathrm{H} 2$ There is a positive relationship between position involvement and (a) affective commitment, (b) calculative commitment and (c) normative commitment

H3 There is a positive relationship between volitional choice and (a) affective commitment, (b) calculative commitment and (c) normative commitment

H4 There is a positive relationship between informational complexity and (a) affective commitment, (b) calculative commitment and (c) normative commitment

A desire to continue a relationship and a willingness to make efforts to maintain it, imply higher chances of customer loyalty. Therefore, we assume there exists a positive 
relationship between commitment and customer loyalty. Several authors support the notion that commitment motivates buyers to act (Gruen 1995; Hennig-Thurau and Klee 1997; Mathieu and Zajac 1990). Liljander and Strandvik (1993) concluded that commitment and behavioral intentions are related concepts. Morgan and Hunt (1994) found significant relationships between the level of a buyer's commitment and his acquiescence, propensity to leave, and cooperation, all of which can be regarded as behavioral intentions. Several organizational commitment studies focused on the intent to leave and turnover as primary behavioral intentions (Rylander, Strutton, and Pelton 1997). Moorman, Zaltman, and Desphandé (1992) suggested that buyers who are committed to a relationship might have a greater propensity to act because of their need to remain consistent with their commitment. Finally, Dick and Basu (1994) stated that the stronger commitment, the more likely the buyer is to overcome potential obstacles in the buyer-seller relationship, resulting in repeat patronage.

The nature of affective, calculative and normative commitment is different, in terms of the focus on the genuine want to stay, the need to stay out of economic and/or psychological investments and the need to stay out of moral obligations. We argue, that the genuine want to stay (affective commitment) and the need to stay out of moral obligations (normative commitment) indeed have a positive impact on customer loyalty, whereas the need to stay out of economic and/or psychological investments (calculative commitment) is negatively related to customer loyalty. Affective and normative commitment can be considered to be driven by mere personal considerations such as personal attachment or personal norms, while calculative commitment is rather based on a rational trade-off of costs and benefits comparing the focal bank with potential alternatives and the sunk costs made to establish the relationship (Meyer and Allen 1984). A customer who is mainly calculatively committed is rather sensitive for any change in the cost/benefit ratio in the marketplace. And therefore, customers 
who show a high level of calculative commitment will be unwilling to voice positive word-ofmouth and complaints, will be unwilling to increase their purchase intentions and will be rather price sensitive, because there is no true intrinsic motivation to be loyal to the bank. The reason here might be that customers who's commitment is based on calculation do not want to invest in the relationship with their bank either by talking positively about the bank or by increasing their purchase intentions. These customers are even more price sensitive and unwilling to complain. It might be expected that they might stay with the bank mainly because of high perceived switching costs or other (perceived) constraints.

Therefore, we formulate the following hypotheses:

H5 There is a positive relationship between affective commitment and (a) word-of-mouth (b) purchase intention, (c) price insensitivity and (d) complaining

H6 There is a negative relationship between calculative commitment and (a) word-ofmouth (b) purchase intention, (c) price insensitivity and (d) complaining

H7 There is a positive relationship between normative commitment and (a) word-ofmouth (b) purchase intention, (c) price insensitivity and (d) complaining

\section{RESEARCH DESIGN}

Data were collected from a sample of customers of three bank offices belonging to one Belgian bank, in three mid-sized towns in the Flemish part of Belgium. In April 2001 customers were randomly asked to fill out the questionnaire. Four hundred and thirty nine correctly filled out questionnaires were collected. The sample was found to be representative for the customers of the focal bank in terms of gender, age, education and occupation. 
The design of the questionnaire was based on multiple-item measurement scales that have been validated and found to be reliable in previous research. All constructs were measured on seven-point Likert scales ranging from completely disagree to completely agree. The measurement items of the different constructs (consumer relationship proneness, volitional choice, position involvement, informational complexity, affective-, calculative- and normative commitment, word-of-mouth, price insensitivity, purchase behavior, and complaint behavior) and their origin are shown in Table 1.

\section{RESULTS}

In order to test our conceptual model, structural equation modeling (SEM) with observed variables was conducted using maximum likelihood estimation in LISREL 8.3. A variancecovariance matrix was calculated using LISREL's companion program PRELIS and was used as input for the path analyses. We subsequently analyzed the overall model, the measurement model and the structural model.

\section{Overall Model Evaluation}

In the overall model, the chi-square value is significant (1878.54 with 673 degrees of freedom), a finding not unusual with large sample sizes (Doney and Cannon 1997). The ratio of chi-square to degrees of freedom is 2.79 , which can be considered as adequate. The values of GFI (0.81) and AGFI (0.78) are somewhat lower than those of CFI (0.88), IFI (0.88) and NNFI (0.87). This result is mainly due to the former measures being more easily affected by sample size and model complexity. In general, the indicated fits are adequate, including RMSEA, which is 0.066 , and SRMR, being 0.010 . Given the objectives of our study, the 
adequacy of these indices, given the fact that the model was developed on theoretical bases, and given the relative complexity of the model, no model re-specifications were made.

\section{Measurement Model Evaluation}

We assessed the quality of the measurement model (see Table 1) on unidimensionality, convergent validity, reliability, and discriminant validity. Evidence for the unidimensionality of each construct was based upon a principal components analysis revealing that the appropriate items loaded at least 0.60 (except for one item of informational complexity) on their respective hypothesized component, with a loading no larger than 0.30 on other components. Convergent validity was supported by a good overall model fit, all loadings being significant ( $\mathrm{p}<0.01$ ), and most $\mathrm{R}^{2}$ exceeding 0.50 (Hildebrandt 1987). Reliability was indicated by composite reliability measures all exceeding 0.70 except for informational complexity and complaint behavior. Discriminant validity was tested in a series of nested confirmatory factor model comparisons in which correlations between latent constructs were constrained to 1 , and indeed chi-square differences were significant for all model comparisons $(\mathrm{p}<0.01)$. In addition, the average percentage of variance extracted for nearly all constructs was greater than 0.50 , except for informational complexity and complaint behavior. In sum, the measurement model (Table 1) is clean, with evidence for unidimensionality, convergent validity, reliability, and discriminant validity.

Insert Table 1 about here

Structural Model Evaluation

Table 2 and Figure 2 contain the detailed results related to the structural model. Almost all proposed relationships between the concepts could be supported. However, we were not able 
to find a significant positive relationship between normative commitment and purchase intentions and normative commitment and complaining. Neither could we show a positive relationship between volitional choice on the one hand and calculative and normative commitment on the other hand.

Insert Table 2 about here

Insert Figure 2 about here

The results clearly show that affective commitment is the most important determinant of loyalty in terms of increased positive word of mouth, increased purchase intention, increased price insensitivity and increased complaining. Calculative commitment on the other hand seems to have the hypothesized negative impact on loyalty. The influence of normative commitment on loyalty is limited in the sense that it only has a small positive relationship with positive word of mouth and price insensitivity.

Affective commitment is clearly positively influenced by position involvement and in a lesser extent by informational complexity and volitional choice. Calculative commitment is positively influenced by position involvement and informational complexity and negatively influenced by volitional choice. And normative commitment is also positively influenced by position involvement and informational complexity and negatively influenced by volitional choice. Relationship proneness as an individual difference variable positively impacts the psychological antecedents underlying commitment: position involvement, volitional choice and informational complexity.

Moreover, the results did not show a significant relationships between normative commitment and purchase intentions nor complaining. We might argue here that when a customer's commitment is based on a moral obligation to stay in the relationship, this 
customer will not necessarily increase its intention to visit the bank more frequently. Furthermore, this customer will not complain about problems with the bank, as this would imply cognitive dissonance.

The unexpected negative relationship between volitional choice and calculative commitment might be explained by the fact that calculative commitment is more a constraint in terms of loyal behavior whereas volitional choice asks for freedom of choice and dedication. Volitional choice therefore limits calculative commitment. The same applies for the negative relationship between volitional choice and normative commitment. Volitional choice is in contradiction with the (moral) obligation to stay in a relationship.

Finally, our results clearly indicate that affective commitment plays a pivotal role in explaining customer loyalty, whereas the impact of normative commitment is positive but rather limited and the impact of calculative commitment seems to be negative. These results support the findings of Geyskens (1998) stating that the use of a global commitment construct would have masked the effect of different types of commitment, stressing the importance of our distinction between affective, calculative and normative commitment. In addition, we explained more than $70 \%$ of the variance in affective commitment, which seems to be the result of the strong impact of position involvement even to the neglect of important antecedents such as for example satisfaction, trust and value (Sirdeshmukh et al. 2002). This means that position involvement is a type of involvement that should be taken into consideration in future research. Moreover, the refinement of the commitment construct as well as the refinement of the antecedents seems to be promising as our empirical results showed clear differences in terms of the directions and magnitudes of the relationships between the constructs. 


\section{MANAGERIAL IMPLICATIONS}

The results of this study clearly show that affective commitment is the most important determinant of word of mouth, purchase intentions, price insensitivity and complaining behavior. Affective commitment deals with having a sense of belongingness to the bank, being happy of being a customer of the bank, feeling emotionally attached to the bank and feeling part of the family of the bank. Moreover, it deals with having a comfortable and reliable relationship with the bank. Improving these aspects of affective commitment exceeds a positive influence on loyalty. A bank therefore, should make sure that a customer is treated as a true individual in which the bank is really interested and cares for. This can be achieved by, among others, actually personalizing the communication efforts of the bank. And by showing attachment and by being of personal meaning to each and every individual customer. In line with our study, especially the effect of position involvement in stimulating affective commitment might not be overlooked. Position involvement can be created by making sure that the image of the bank comes close to the lifestyle of the customer and that the bank reflects the personality of the customers in terms of their values and norms. Careful analyses of which norms and values customers in the target market expect to be reflected in their bank is important here and based upon this the concise selection of a well defined segment. Moreover, our study indicates that the bank should target those customers who are intrinsically inclined to engage in relationship with banks. It is important to realize that not every customer is willing to engage in long-term relationships and therefore the bank should not waste resources on targeting these unwilling customers. Relationship prone customers tend to reveal high position involvement which impacts affective commitment and finally loyalty. 
Finally, our study shows the possible danger of the role of calculative commitment as this has a negative impact on loyalty. Moreover, calculative commitment seems to function as an exit barrier as long as the benefits of the current bank exceed the costs of switching. Apparently, customers who feel constrained in their relationship do not experience the required dedication to be loyal to the bank. This implies that the bank should avoid calculative commitment by not stressing the cost benefit relationship of the offered services but rather emphasizing the personal attachment and the comfort of having an ongoing relationship with the bank.

\section{LIMITATIONS AND DIRECTIONS FOR FUTURE RESEARCH}

Our research should be seen as a preliminary attempt to address an issue that has important implications for marketing theory and practice. Any preliminary attempt will involve a number of limitations. However, acknowledgement of these limitations also suggests new directions for future studies.

A first potential shortcoming in the study is common method bias. As we used one single questionnaire to measure all constructs included, the relationships between these constructs may be somewhat inflated. No database information could be used as input for measuring actual behavior. This study could be improved with access to more substantial data on customer purchase histories that are not subject to potential recall loss. It would then be possible to look at longer strings of purchases and to perhaps incorporate contextual information. With respect to the measurement items, we have to conclude that the scales used to measure informational complexity and complaining could be improved. In a follow-up study we have to develop a more appropriate scale. Moreover, it must be recognized that our sample of Belgian bank customers cannot necessarily be generalized. This limits the findings as relevant only to these types of customers and service providers. Future studies need to 
assess the generalizability of our findings to other contexts. Furthermore, future research should concentrate on issues that could help management identifying, attracting and retaining the relationship prone customers as they will have strong position involvement, reveal a high affective commitment and will most probably be loyal to the bank.

In conclusion, it is hoped that these research results will serve as a stimulus for additional empirical research involving ongoing relationships in a services setting. 
TABLE 1

Measurement Model

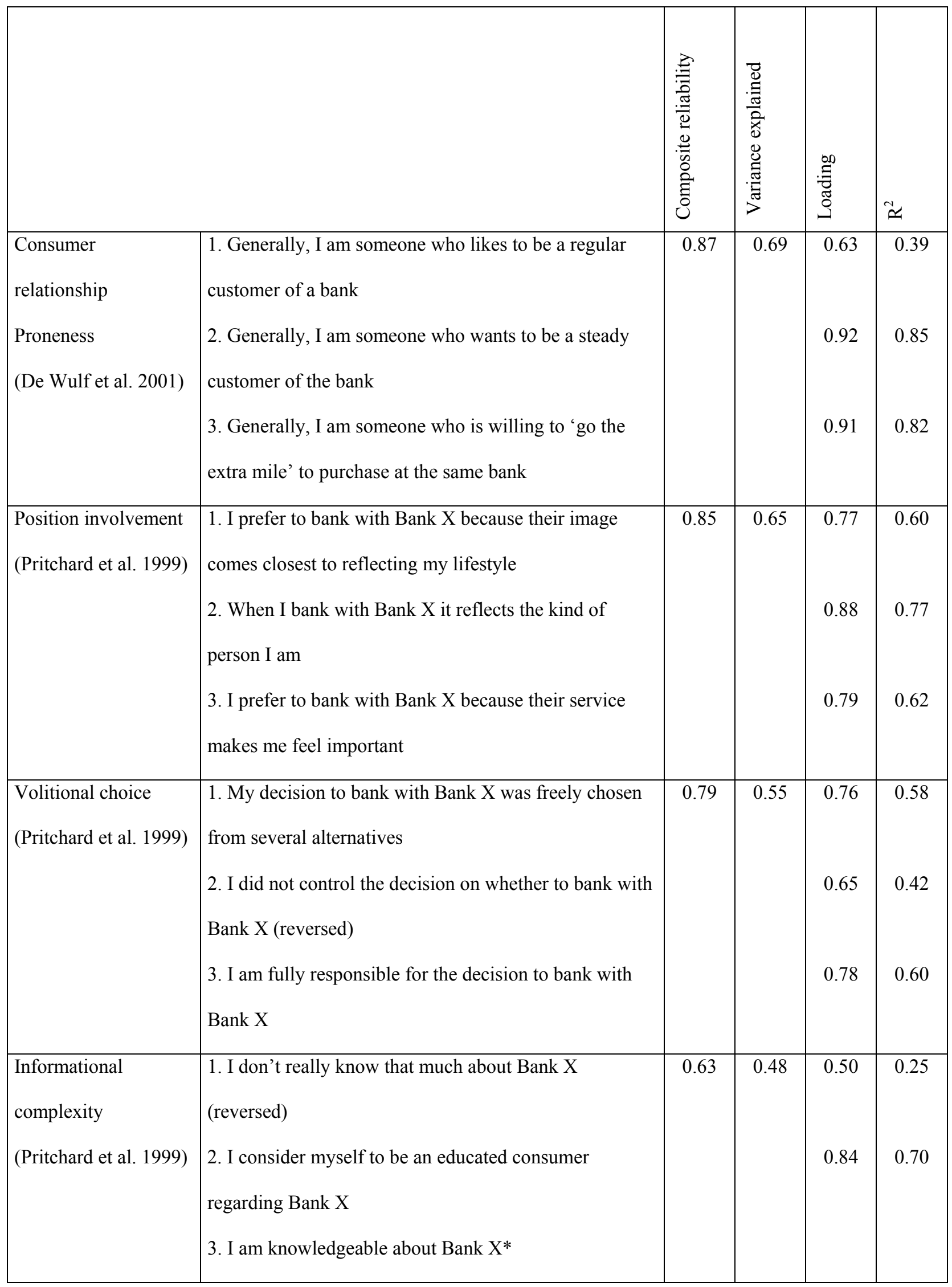




\begin{tabular}{|c|c|c|c|c|c|}
\hline $\begin{array}{l}\text { Affective } \\
\text { commitment } \\
\text { (based upon: Allen } \\
\text { and Meyer 1990) }\end{array}$ & $\begin{array}{l}\text { 1. I do feel a strong sense of belonging to Bank X } \\
\text { 2. I stay with Bank X because I am very happy to be } \\
\text { their customer } \\
\text { 3. I stay with Bank X because of the comfortable } \\
\text { relationship I have with Bank X } \\
\text { 4. Bank X has a great deal of personal meaning for me* } \\
\text { 5. I do feel like "part of the family" at Bank X } \\
\text { 6. I do feel "emotionally attached" to Bank X }\end{array}$ & 0.90 & 0.64 & $\begin{array}{l}0.78 \\
0.77\end{array}$ & $\begin{array}{l}0.61 \\
0.59\end{array}$ \\
\hline $\begin{array}{l}\text { Calculative } \\
\text { commitment } \\
\text { (based upon: Allen } \\
\text { and Meyer 1990) }\end{array}$ & $\begin{array}{l}\text { 1. It would be too costly for me to leave Bank X, } \\
\text { therefore I stay } \\
\text { 2. One of the major reasons I continue to bank with } \\
\text { Bank X is that leaving would require considerable } \\
\text { personal sacrifice } \\
\text { 3. I stay with Bank X because the costs of changing } \\
\text { exceed the benefits } \\
\text { 4. If I had not already put so much of myself in Bank X } \\
\text { I might consider going elsewhere* }\end{array}$ & 0.88 & 0.71 & 0.81 & 0.65 \\
\hline $\begin{array}{l}\text { Normative } \\
\text { commitment } \\
\text { (based upon: Allen } \\
\text { and Meyer 1990) }\end{array}$ & $\begin{array}{l}\text { 1. I do feel an obligation to remain with Bank X } \\
\text { 2. Even if it were to my advantage, I do feel it would be } \\
\text { wrong to leave Bank X now } \\
\text { 3. I would feel guilty if I left Bank X now } \\
\text { 4. Bank X deserves my loyalty* } \\
\text { 5. I would not leave Bank X now, because I have a } \\
\text { sense of obligation to it } \\
\text { 6. I owe a great deal to Bank X }\end{array}$ & 0.84 & 0.52 & 0.71 & 0.50 \\
\hline $\begin{array}{l}\text { Word-of-mouth } \\
\text { (based upon: Zeithaml } \\
\text { et al. 1996) }\end{array}$ & $\begin{array}{l}\text { 1. I say positive things about Bank } \mathrm{X} \text { to other people } \\
\text { 2. I recommend Bank } \mathrm{X} \text { to someone who seeks advice }\end{array}$ & 0.90 & 0.74 & 0.82 & 0.84 \\
\hline
\end{tabular}




\begin{tabular}{|c|c|c|c|c|c|}
\hline & 3. I encourage friends to go to Bank $X$ & & & 0.79 & 0.63 \\
\hline $\begin{array}{l}\text { Purchase intentions } \\
\text { (based upon: Zeithaml } \\
\text { et al. 1996) }\end{array}$ & $\begin{array}{l}\text { 1. I consider Bank } \mathrm{X} \text { as my first choice* } \\
\text { 2. I go more often to Bank } \mathrm{X} \text { in the next few weeks } \\
\text { 3. I go less often to Bank X in the next few weeks } \\
\text { (reversed) }\end{array}$ & 0.74 & 0.60 & $\begin{array}{l}0.91 \\
0.61\end{array}$ & $\begin{array}{l}0.82 \\
0.38\end{array}$ \\
\hline $\begin{array}{l}\text { Price-insensitivity } \\
\text { (based upon: Zeithaml } \\
\text { et al. 1996) }\end{array}$ & $\begin{array}{l}\text { 1. When the services I usually buy at Bank X are } \\
\text { charged less at another Bank I go to that bank (reversed) } \\
\text { 2. I am willing to go to another bank that offers more } \\
\text { attractive prices (reversed) } \\
\text { 3. I am willing to pay a higher price than other banks } \\
\text { charge for the benefits I currently receive from Bank X* }\end{array}$ & 0.76 & 0.62 & 0.81 & 0.57 \\
\hline $\begin{array}{l}\text { Complaint behavior } \\
\text { (based upon: Zeithaml } \\
\text { et al. 1996) }\end{array}$ & $\begin{array}{l}\text { 1. I switch to a competitor if I experience a problem } \\
\text { with Bank X* } \\
\text { 2. I complain to other consumers if I experience a } \\
\text { problem with Bank X (reversed) } \\
\text { 3. I complain to an external agency if I experience a } \\
\text { problem with Bank X (reversed) } \\
\text { 4. I complain to Bank X'SB: employees if I experience a } \\
\text { problem with Bank X* }\end{array}$ & 0.63 & 0.47 & 0.61 & 0.37 \\
\hline
\end{tabular}

* not included in structural model 
TABLE 2

Structural Model

\begin{tabular}{|c|c|c|}
\hline Parameter & $\begin{array}{l}\text { Hypo- } \\
\text { Thesis }\end{array}$ & $\begin{array}{c}\text { ML } \\
\text { estimate }\end{array}$ \\
\hline Relationship proneness $\rightarrow$ position involvement & $1 \mathrm{a}(+)$ & $0.56^{* *}$ \\
\hline Relationship proneness $\rightarrow$ volitional choice & $1 \mathrm{~b}(+)$ & $0.37 * *$ \\
\hline Relationship proneness $\rightarrow$ informational complexity & $1 \mathrm{c}(+)$ & $0.21 * *$ \\
\hline Position involvement $\rightarrow$ affective commitment & $2 \mathrm{a}(+)$ & $0.79 * *$ \\
\hline Position involvement $\rightarrow$ calculative commitment & $2 \mathrm{~b}(+)$ & $0.14 * *$ \\
\hline Position involvement $\rightarrow$ normative commitment & $2 \mathrm{c}(+)$ & $0.40^{* *}$ \\
\hline Volitional choice $\rightarrow$ affective commitment & $3 a(+)$ & $0.12 * *$ \\
\hline Volitional choice $\rightarrow$ calculative commitment & $3 b(+)$ & $-0.20 * *$ \\
\hline Volitional choice $\rightarrow$ normative commitment & $3 \mathrm{c}(+)$ & $-0.22 * *$ \\
\hline Informational complexity $\rightarrow$ affective commitment & $4 \mathrm{a}(+)$ & $0.11 * *$ \\
\hline Informational complexity $\rightarrow$ calculative commitment & $4 \mathrm{~b}(+)$ & $0.12 *$ \\
\hline Informational complexity $\rightarrow$ normative commitment & $4 \mathrm{c}(+)$ & $0.26^{* *}$ \\
\hline Affective commitment $\rightarrow$ word-of-mouth & $5 \mathrm{a}(+)$ & $0.62 * *$ \\
\hline Affective commitment $\rightarrow$ purchase intentions & $5 \mathrm{~b}(+)$ & $0.56^{* *}$ \\
\hline Affective commitment $\rightarrow$ price insensitivity & $5 \mathrm{c}(+)$ & $0.38^{* *}$ \\
\hline Affective commitment $\rightarrow$ complaining & $5 \mathrm{~d}(+)$ & $0.21 * *$ \\
\hline Calculative commitment $\rightarrow$ word-of-mouth & $6 \mathrm{a}(+)$ & $-0.11 * *$ \\
\hline Calculative commitment $\rightarrow$ purchase intentions & $6 \mathrm{~b}(+)$ & $-0.18^{* *}$ \\
\hline Calculative commitment $\rightarrow$ price insensitivity & $6 \mathrm{c}(+)$ & $-0.10 *$ \\
\hline Calculative commitment $\rightarrow$ complaining & $6 \mathrm{~d}(+)$ & $-0.33^{* *}$ \\
\hline Normative commitment $\rightarrow$ word-of-mouth & $7 \mathrm{a}(+)$ & $0.10^{*}$ \\
\hline Normative commitment $\rightarrow$ purchase intentions & $7 \mathrm{~b}(+)$ & 0.07 \\
\hline Normative commitment $\rightarrow$ price insensitivity & $7 \mathrm{c}(+)$ & $0.11 *$ \\
\hline Normative commitment $\rightarrow$ complaining & $7 \mathrm{~d}(+)$ & -0.05 \\
\hline Squared multiple correlations for structural equations & & Estimate \\
\hline Position involvement & & 0.31 \\
\hline Volitional choice & & 0.14 \\
\hline Informational complexity & & 0.04 \\
\hline Affective commitment & & 0.71 \\
\hline Calculative commitment & & 0.06 \\
\hline Normative commitment & & 0.25 \\
\hline Word-of-mouth & & 0.43 \\
\hline Purchase intention & & 0.36 \\
\hline Price insensitivity & & 0.19 \\
\hline Complaining & & 0.14 \\
\hline
\end{tabular}


FIGURE 1

Conceptual Model

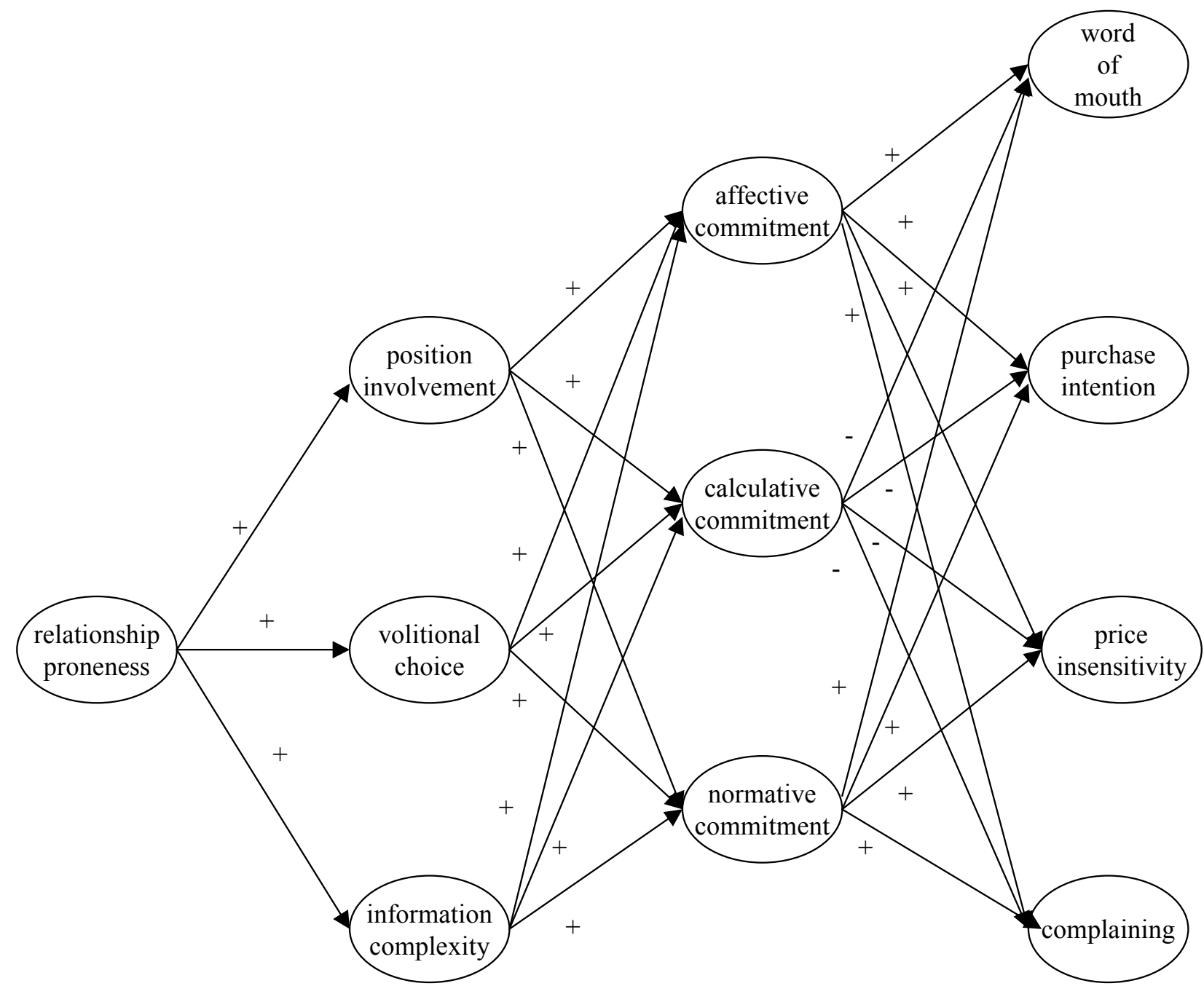


FIGURE 2

\section{Structural Model}

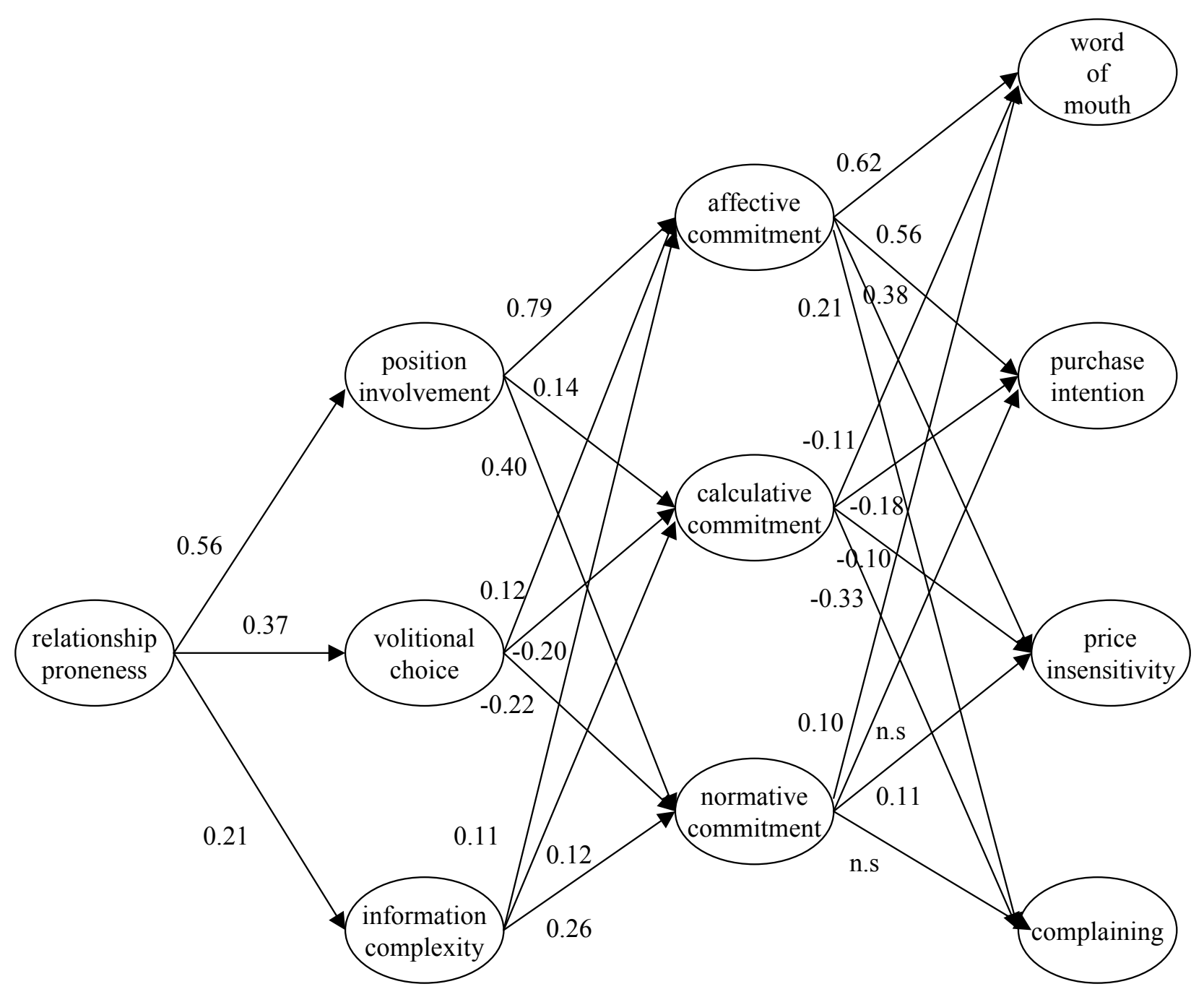




\section{LITERATURE}

Allen, J.P. \& J.P. Meyer (1990). The measurement and antecedents of affective, continuance, and normative commitment to the organization. Journal of Occupational Psychology, 63, 1-18.

Bagozzi, R.P. (1975). Marketing as Exchange. Journal of Marketing, 39, 32-9.

Bagozzi, R.P. (1993). On the Neglect on Volition in Consumer Research: A Critique and

Proposal. Psychology \& Marketing, 10 (May/June), 215-237.

Barnes, J.G. (1995). The Quality and Depth of Customer Relationships, in Proceedings of the $24^{\text {th }}$ EMAC Conference, Michelle Bergadaà, ed. Cergy Pontoise: European Marketing Academy 1393-402.

Barnes, J.G. (1997). Closeness, strength, and satisfaction: examining the nature of relationships between providers and financial services and their retail customers. Psychology and Marketing, 14 (8), 765-90.

Beatty S., P. Homer, \& L.R. Kahle (1988). The Involvement-Commitment Model: Theory and Implications. Journal of Business Research, 16 (2), 149-67.

Bem, D.J. (1967). Self-Perception: An Alternative Interpretation of Cognitive Dissonance Phenomena. Psychological Review 74, 183-200.

Bendapudi, N. \& Berry, L.L. (1997). Customers' motivations for maintaining relationship with service providers. Journal of Retailing, 73 (1), 15-37.

Bolding, J., A. Kalra, R. Staelin, \& V.A. Zeithaml (1993). A Dynamic Process Model of Service Quality: From Expectations to Behavioral Intentions. Journal of Marketing Research, 30, 7-27.

Buchanan, T. (1985). Commitment and Leisure Behavior: A Theoretical Perspective, Leisure Sciences, 7 (4), 401-420.

Christy, R., Oliver, G. \& Penn, J. (1996). Relationship Marketing in Consumer Markets. Journal of Marketing Management, 12, 175-87.

Cialdini, R.B., R.J. Borden, A. Thorne, M.R. Walker, S. Freeman \& L.R. Sloan (1976). Basking in Reflected Glofy: Three (Football) Field Studies. Journal of Personality \& Social Psychology 34, 366-375.

Cronin, J Joseph \& S.A. Taylor (1992). Measuring Service Quality: A Re-examination and Extension. Journal of Marketing, 56, 55-68.

Crosby, L.A. \& J.R. Taylor (1983). Psychological Commitment and Its Effects on PostDecision Evaluation and Preference Stability Among Voters. Journal of Consumer Research 9, 413-431.

Davis, J. Charlene (1995). Dependency, Self-interest, and Relationship Marketing. Journal of Marketing Theory \& Practice, 3 (4), 17-23.

Day, G.S. (1969). A Two-Dimensional Concept of Brand Loyalty. Journal of Advertising Research, 9 (3), 29-35.

De Wulf, K., G. Odekerken-Schröder \& D. Iacobucci (2001). Investments in Consumer Relationships:

a Cross-Country and Cross-Industry Exploration. Journal of Marketing, 65, 33-50.

Dick, A.S. \& Basu, K. (1994). Customer loyalty: toward an integrated conceptual framework. Journal of the Academy of Marketing Science, 22 (2), 99-113.

Doney, P.S. \& Cannon, J.P. (1997). An examination of the nature of trust in buyer-seller relationships. Journal of Marketing, 61 (2), 35-51.

Festinger, L. (1957). A theory of cognitive dissonance. Stanford, CA: Stanford University Press

Freedman, J.L. (1964). Involvement, Discrepancy and Change. Journal of Abnormal \& Scocial Psychology 68, 290-295.

Ganesan, S. (1994). Negotiation strategies and the nature of channel relationships. Journal of Marketing Research, 58 (2), 183-203.

Geyskens, I. (1998). Trust, Satisfaction, and Equity in Marketing Channel Relationships, doctoral dissertation, Catholic University of Louvain. 
Geyskens, I, J.B. Steenkamp, L.K. Scheer \& N. Kumar (1996). The Effects of Trust and Interdependence on Relationship Commitment: A Transatlantic Study. International Journal of Research in Marketing, 13 (4), 303-318.

Gruen, T. (1995). The outcome set of relationship marketing in consumer markets. International Business Review, 4, 447-469.

Hennig-Thurau, T. \& A. Klee (1997). The Impact of Customer Satisfaction and Relationship Quality on Customer Retention: A Critical Reassessment and Model Development. Psychology and Marketing, 14 (8), 737-364.

Hildebrandt, L. (1987). Consumer Retail Satisfaction in Rural Areas: A Re-analysis of Survey Data. Journal of Economic Psychology, 8 (1), 19-42.

Jacoby, J. \& R. W. Chestnut (1978). Brand Loyalty: Measurement and Management. New York: John Wiley and Sons, Inc.

Liljander, V. \& T. Strandvik (1993). Estimating Zones of Tolerance in Perceived Service Quality and Perceived Service Value. International Journal of Service Industry Management, 4 (2), 6-28.

Mathieu, J.E. \& D.M. Zajac (1990). A Review and Meta-Analysis of the Antecedents, Correlates, and Consequences of Organizational Commitment. Psychological Bulletin, 108 (2), 171-194.

Meyer, J.P. \& N.J. Allen (1984). Testing the 'Side-Bet Theory' of Organizational Commitment: Some Methodological Considerations. Journal of Applied Pscyhologie, 69 (3), 372-379.

Millar, M.G. \& A. Tessar (1986). Thought Induced Attitude-Change: The Effects of Schema, Structure and Commitment. Journal of Personality \& Social Psychology, 51 (2), 259-269.

Moorman, C., G. Zaltman \& R. Deshpandé (1992). Relationships between Providers and Users of Market Research: The Dynamics of Trust within and between Organizations. Journal of Marketing Research, 29 (3), 314-328.

Moorman, C., R. Desphandé, \& G. Zaltman (1993). Factors Affecting Trust in Market Research Relationships. Journal of Marketing, 57 (1), 81-101.

Morgan, R.S. \& Hunt, S.D. (1994). The commitment-trust theory of relationship marketing. Journal of marketing, 58 (July), 20-38.

Oliver, R.L \& J.E. Swan (1989). Consumer Perceptions of Interpersonal Equity and Satisfaction in Transaction: A field survey approach. Journal of Marketing, 53 (2), 21-35.

Palmer, A. (1995). Relationship Marketing: a New Philosophy for Marketing or a New Function?. Proceedings of the Seventh Bi-Annual World Marketing Congress, Ken Grant and Ian Walker, eds. Monash University: Melbourne, 15/130-4.

Pritchard, M.P., M.E. Havitz, \& D.R. Howard (1999). Analyzing the Commitment-Loyalty Link in Service Contexts. Journal of the Academy of Marketing Science, 27 (3), 333-48.

Rylander, D., D. Strutton \& L.E. Pelton (1997). Towards a Synthesized Framework of Relational Commitment: Implications for Marketing Channel Theory and Practice. Journal of Marketing Theory \& Practice, 5 (2), 58-71.

Salancik, G. R. (1977). Commitment and the Control of Organizational Behavior and Belief. In New Directions in Organizational Behavior Eds. B.M. Staw \& G.R. Salancik. Chicago: St. Clair, 1-54.

Shamir, B (1988). Commitment and Leisure. Sociological Perspectives, 31 (April), 238-258.

Singh, J. (1991). Industry Characteristics and Consumer Dissatisfaction. Journal of Consumer Affairs, 25 (1), 19- 57.

Sirdeshmukh, D., J. Singh \& B. Sabol (2002). Customer Trust, Value and Loyalty in Relational Exchanges. Journal of Marketing, 66(1), 15-38.

Smith, J.B. \& D.W. Barclay (1997). The Effects of Organizational Differences and Trust on the Effectiveness of Selling Partner Relationships. Journal of Marketing, 61 (1), 3-21. 
Zeithaml, V.A., Berry, L.L. \& Parasuraman, A. (1996). The behavioral consequences of service quality. Journal of Marketing, 60 (April), 31-46. 